\title{
Monitoring Level Sampah pada Sungai di Sekitar Pemukiman Melalui Sensor Alarm Berbasis Realtime
}

\author{
Adela Dewi Fortuna Putry ${ }^{1)}$, Durrotul Faiqoh ${ }^{1)}$, Nurul Hikmah Widyansyah ${ }^{2)}$ \\ ${ }^{1}$ Sistem Informasi, Fakultas Teknologi Informasi dan Industri, Insititut Teknologi Telkom Surabaya \\ ${ }^{2}$ Teknik Industri, Fakultas Teknologi Informasi dan Industri, Insititut Teknologi Telkom Surabaya \\ J1. Ketintang No.156, Kota Surabaya, Jawa Timur 60231, Indonesia \\ adeladewi@student.ittelkom-sby.ac.id
}

\begin{abstract}
Abstrak
Budaya lama membuang sampah ke sungai khususnya di sekitar permukiman menunjukkan bahwa setiap upaya untuk menjaga kebersihan lingkungan membutuhkan perubahan besar dalam pola pikir masyarakat. Akibatnya lingkungan yang buruk menjadi dampaknya. Sebagai contoh aroma tidak sedap, berkembangnya bibit penyakit, rusaknya ekosistem dan pendangkalan aliran sungai. Oleh karena itu, dalam penelitian ini, dikembangkan rancangan alat untuk membantu mendeteksi permasalahan sampah di sungai pada kawasan permukiman. Alat berupa sensor yang mampu mendeteksi serta mengontrol level sampah di sungai. Monitoring status mutu kebersihan sungai mengunakan metode indeks pencemaran yang dilengkapi dengan kamera penangkap citra sampah serta sensor alarm untuk menghasilkan output berupa bunyi peringatan apabila level sampah yang terdeteksi telah melebihi batas tercemarnya lingkungan sungai. Adapun parameter yang digunakan untuk menghasilkan bunyi peringatan bilamana level sampah telah memenuhi 50 persen dari area sungai, maka selanjutnya dilakukan gerakan pembersihan sungai agar alarm dapat berhenti berbunyi supaya tidak menimbulkan kebisingan di sekitar pemukiman.
\end{abstract}

Kata kunci: monitoring, level sampah, permukiman, sungai, sensor alarm

\section{Pendahuluan}

Sampah merupakan sisa kegiatan sehari-hari manusia dan/atau dari proses alam yang berbentuk padat (Suyoto, 2008). Meningkatnya laju produksi sampah tidak hanya sejajar dengan laju pertumbuhan penduduk, tetapi juga sejalan dengan meningkatnya masyarakat yang konsumtif. Di sisi lain, kapasitas penanganan sampah yang dilakukan masyarakat maupun pemerintah daerah belum optimal. Sampah yang tidak dikelola dengan baik akan berpengaruh terhadap lingkungan dan kesehatan masyarakat sekitarnya (Riswan, dkk., 2011).

Kuantitas sampah secara nasional mencapai 175.000 ton per hari atau setara 64 juta ton per tahun. Jika menggunakan asumsi sampah yang dihasilkan, maka hasil akumulasi setiap orang menghasilkan sampah seberat $0,7 \mathrm{~kg}$ per hari. Berdasarkan sumbernya, sampah didominasi berasal dari rumah tangga (48\%), pasar tradisional (24\%), dan kawasan komersial (9\%). Sisanya dari fasilitas publik, sekolah, kantor, jalan, dan sebagainya (Baqiroh, 2019).

Sampah melekat sebagai musuh bagi lingkungan karena mampu menimbulkan dan mencemari lingkungan. Lingkungan yang tercemar oleh pembuangan sampah berakibat kotor, kumuh, serta timbul aroma tak sedap yang kemudian akan menimbulkan penyakit. Pembuangan sampah merupakan masalah yang harus diperhatikan secara pokok supaya tidak mengakibatkan dampak yang cukup serius dalam masalah lingkungan di Indonesia.

Masyarakat seringkali terbiasa membuang limbah rumah tangga ke sungai. Akibatnya kondisi sungai menjadi tidak terawat dan terganggu nilai fungsionalnya. Sebagai tangan yang bertanggung jawab atas lingkungan sekitar, naluri untuk menjaga kebersihan sungai patut tumbuh karena masyarakat berperan sebagai pihak pertama yang harus berusaha mengatasi permasalahan tersebut. 
Berdasarkan penelitian yang telah mengkaji persoalan pencemaran sungai, seperti Firmansyah (2015) yang membahas partisipasi masyarakat sekitar sungai dalam menjaga kebersihan lingkungan sungai. Hasil penelitian tersebut menyebutkan bahwa rendahnya partisipasi masyarakat dalam menjaga kebersihan sungai disebabkan kebiasaan yang menganggap membuang sampah ke sungai lebih praktis dan mudah. Selain itu, kurang memadainya sarana dan 10 prasarana pembuangan sampah menyebabkan masyarakat memilih membuang sampah ke sungai. Kemudian Purwanto (2018) melakukan penelitian terhadap perilaku sadar lingkungan dipengaruhi oleh pendidikan dan pendapatan, keterbatasan biaya ketersediaan sarana dan tempat menjadi kendala utama dalam mewujudkan perilaku sadar lingkungan (Wijaya dan Muchtar, 2019).

Terdapat beberapa solusi yang telah diberikan oleh pihak badan pemerintah terkait, perangkat desa maupun komunitas relawan untuk mengatasi masalah sampah di sungai. Diantaranya yaitu dibangunnya Banksasuci oleh komunitas relawan. Banksasuci merupakan singkatan dari Bank Sampah Sungai Cisadane yang terletak di kawasan Panunggangan barat, Cibodas, Tangerang, yang dikemas dalam bentuk bangunan teduh dilengkapi dengan fasilitas-fasilitas pengelolaan sampah didalamnya. Namun solusi tersebut belum cukup membuat masyarakat merasa jera akan buruknya membuang sampah di sungai (Putri, 2017).

Oleh karena itu, untuk dapat mengontrol mutu sungai agar selalu bebas dari sampah, maka diperlukan alat bantu untuk memonitoringnya. Untuk membantu masalah tersebut, dirancang suatu peralatan instrumentasi berupa alat pendeteksi level sampah berbasis realtime dan dikombinasikan dengan mikrokontroller Arduino Nano yang dapat menampilkan informasi hasil pengukurannya pada buzzer yang berbunyi dan mengirim data pada lembaga pemerintah terkait, seperti KLHK (Kementrian Lingkungan Hidup dan Kehutanan).

\section{Metode Penelitian}

Metode yang digunakan dalam penelitian ini secara ringkas disajikan melalui flowchart pada gambar 1. Sebagai langkah awal dilakukan penentuan objek dengan mengamati kondisi yang kerap terjadi di lingkungan sekitar hingga diperoleh sampel permasalahan yang dapat kita angkat untuk selanjutnya dilakukan observasi. Dari beberapa permasalahan, diputuskan bahwa dalam penelitian ini mengangkat permasalahan mengenai monitoring level sampah sungai di sekitar pemukiman melalui sensor alarm.

Identifikasi masalah dilakukan untuk menentukan permasalahan yang melandasi penelitian ini. Berdasarkan hasil identifikasi awal, diperoleh permasalahan bahwa kondisi kebersihan sungai di sekitar pemukiman membutuhkan tindak perhatian lebih. Rumusan masalah yang diambil yaitu "Bagaimana pengembangan sensor alarm berbasis realtime untuk monitoring level sampah di sungai sekitar pemukiman dengan menggunakan metode indeks pencemaran?" Dengan harapan rumusan masalah ini dapat terjawab dan membantu untuk turut memberikan solusi terhadap permasalahan tersebut.

Kegiatan studi literatur dilakukan supaya mendapatkan informasi serta memperdalam landasan teori dari penelitian yang akan dilakukan. Studi literatur didapatkan melalui berbagai sumber terkini dan terpercaya seperti artikel dari jurnal dan prosiding, website, maupun buku terkait penelitian.

\section{Hasil dan Pembahasan}

\subsection{Pengelolaan Sampah Berdasarkan Aspek-Aspek Tertentu}

\section{a. Aspek Hukum dan Peraturan}

Pelaksanaan pengelolaan sampah diperlukan suatu kepastian hukum, kejelasan tanggung jawab dan kewenangan pemerintah pusat dan daerah sehingga pengelolaan sampah dapat berjalan secara proporsional dan terstruktur. 


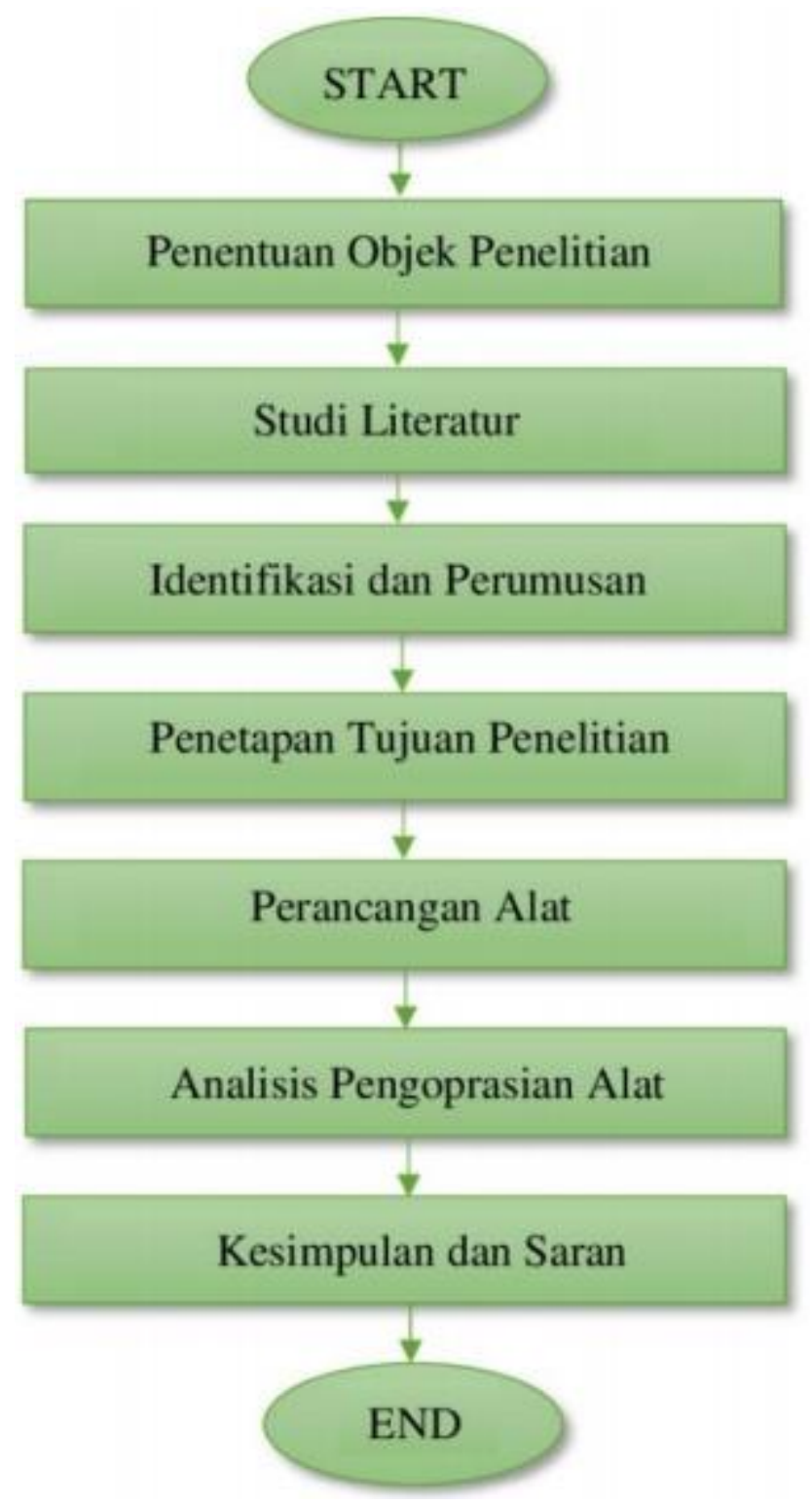

Gambar 1. Flowchart metodologi

Landasan hukum yang mengatur tentang permasalahan sampah yaitu Peraturan Daerah No. 5 tahun 2004 tentang Retribusi Pelayanan Persampahan atas Penyelenggaraan Kebersihan dan Pengelolaan Persampahan. Peraturan daerah tersebut mengatur tentang penyelenggaraan kebersihan lingkungan, ketentuan pembuangan dan pengelolaan sampah, retribusi sampah, serta sanksi hukum yang ditetapkan oleh Pemerintah Kabupaten. Namun selama ini, belum ada penegakkan secara tegas oleh aparat dalam hal pelanggaran mengenai masalah sampah karena sukarnya mencari bukti yang cukup kuat di lapangan (Riswan, dkk., 2011). Di sisi lain, masyarakat menilai fasilitas pembuangan sampah yang ada belum sesuai dengan penempatan strategis dan ideal sehingga membuat masyarakat membuang sampah sembarangan.

\section{b. Aspek Peran Serta Masyarakat}

Berdasarkan bentuk operasional, tingkah laku manusia terbagi dalam tiga jenis yaitu pengetahuan, sikap dan tindakan (Notoatmojo, 1985). Adanya campur tangan masyarakat sangat membantu dalam pelaksanaan pengelolaan sampah sesuai dengan perencanaan yang disiapkan. Dengan dilakukannya suatu pendekatan serta pembinaan yang sesuai dengan budaya masyarakat setempat secara berkala, memungkinkan adanya perubahan perilaku yang positif. 


\subsection{Faktor-faktor yang Berkorelasi dengan Cara Pengelolaan Sampah \\ a. Faktor Tingkat Pendidikan}

Faktor yang menimbulkan masalah sampah satu diantaranya yaitu minimnya pendidikan. Untuk meningkatkan kesadaran masyarakat akan upaya pengelolaan sampah hasil produksinya, diperlukan adanya pemerataan pengetahuan masyarakat secara pendidikan formal maupun non formal (Hadiwiyoto, 1983).

\section{b. Faktor Tingkat Pendapatan}

Kemiskinan membuat orang tidak peduli dengan lingkungan. Orang dalam keadaan miskin dan lapar, pusing dengan kebutuhan keluarga, pendidikan dan lain-lain, bagaimana dapat berpikir tentang peduli lingkungan. Misalnya tidak mampu menyediakan media pewadahan atau tempat sampah di rumah tangga karena faktor ketidakmampuan secara ekonomi (Neolaka, 2008).

\section{c. Faktor Perilaku terhadap Kebersihan Lingkungan}

Perilaku dibagi menjadi 3 secara bentuk operasionalnya, yaitu pengetahuan, sikap dan tindakan (Notoatmojo, 1985). Satu diantara penerapan perilaku hidup bersih dan sehat (PHBS) yaitu tidak membuang sampah secara sembarangan. Berdasarkan aspek rusaknya, daya dukung lingkungan terdapat dua jenis bencana, yaitu secara faktor internal dan eksternal. Secara internal, kerusakan berasal dari alam sendiri. Sedangkan secara ekternal, kerusakan lingkungan berasal dari aktivitas manusia, seperti limbah rumah tangga yang dibuang di aliran sungai. Adapun satu diantara faktor yang menimbulkan permasalahan sampah yang sukar dipecahkan yaitu mentalitas manusia (Hadiwiyoto, 1983).

\subsection{Perancangan Alat}

Solusi yang diberikan dalam penelitian ini yaitu raancangan alat instrumentasi berupa alat monitoring level sampah berbasis realtime. Adapun diagram alir dari proses perancangan alat dalam penelitian ini ditunjukkan pada gambar berikut:

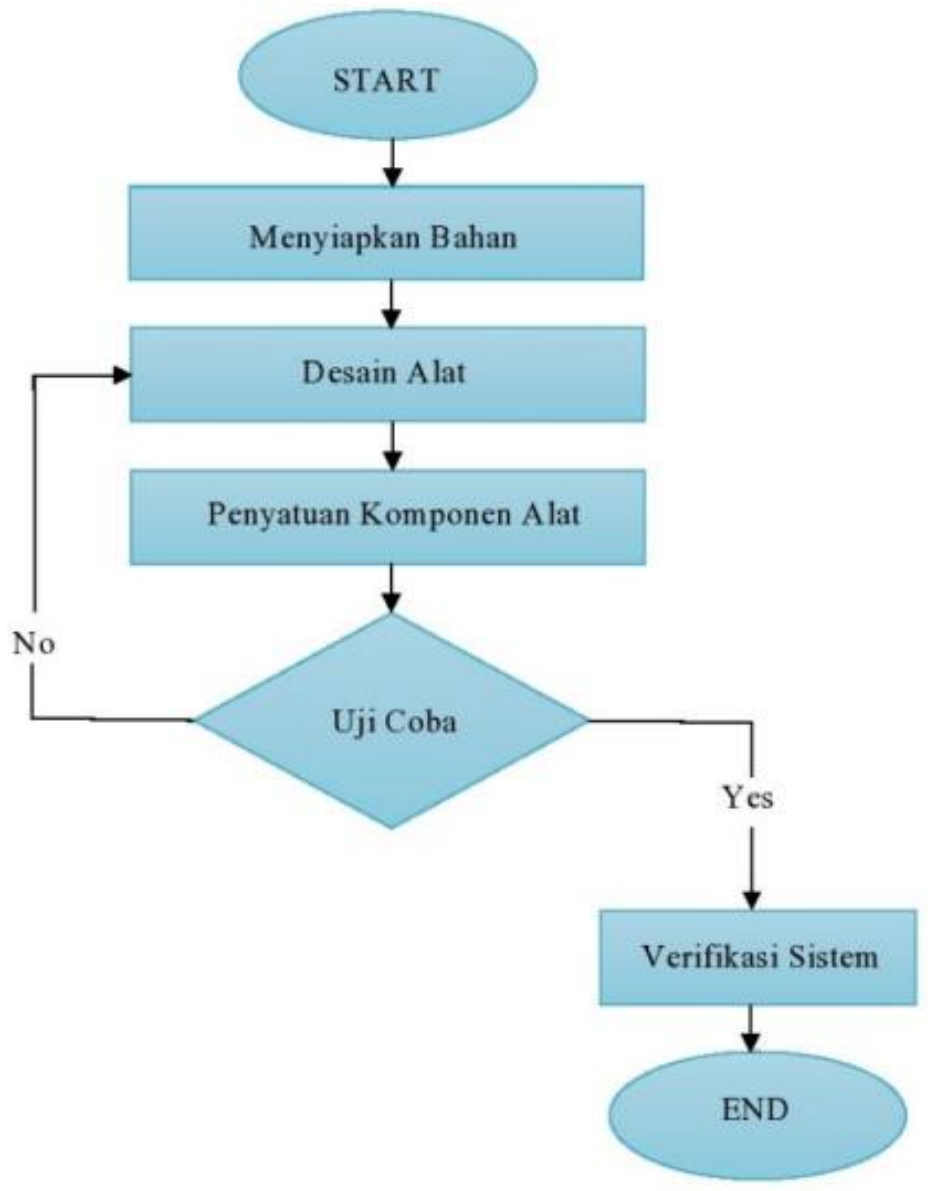

Gambar 2. Flowchart perancangan alat 
Langkah pertama yang dilakukan dalam perancangan alat adalah menyiapkan bahan-bahan yang dibutuhkan. Perancangan alat secara dasar dilakukan ketika bahan-bahan sudah tersedia. Tahap berikutnya penyatuan komponen-komponen pada alat yang telah dibuat pada tahap perancangan dasar. Setelah keseluruhan komponen dirakit, maka akan dilakukan uji coba alat untuk menguji serta memastikan bahwa alat tersebut layak.

\subsection{Pengembangan Alat}

Untuk merancang alat monitoring level sampah di sungai, dalam penelitian ini memerlukan bahanbahan yang terdiri dari input, pemroses, dan output (Lestari, dkk. 2019). Adapun digambarkan sebagai berikut:

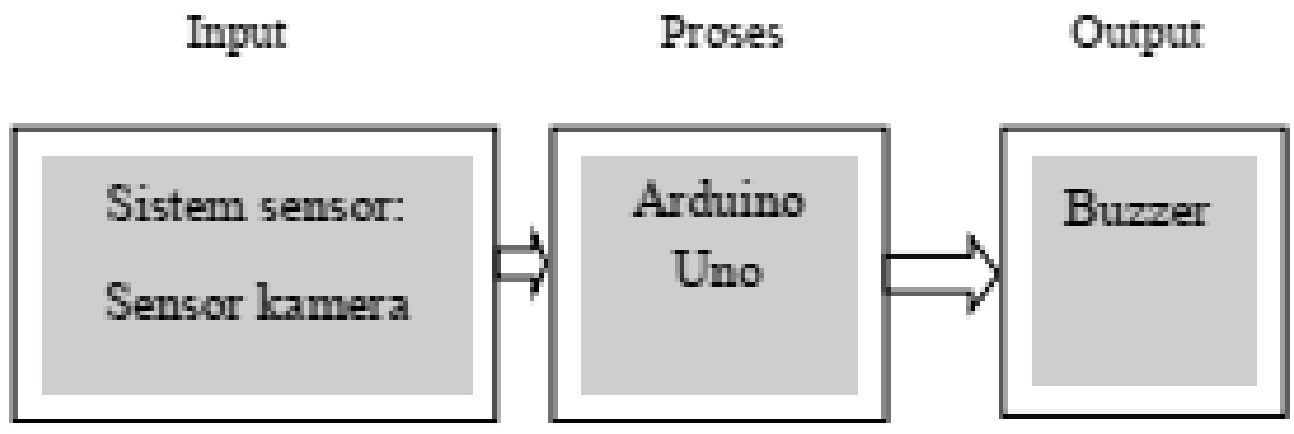

Gambar 3. Diagram blok rancangan alat monitoring level sampah

Peralatan yang dibutuhkan untuk merancang alat dapat dilihat pada tabel 1.

Tabel 1. Tabel Peralatan yang Dibutuhkan

\begin{tabular}{|c|c|c|}
\hline No. & Peralatan & Fungsi \\
\hline 1. & Sensor kamera & $\begin{array}{l}\text { Untuk menangkap citra gambar sampah di } \\
\text { aliran sungai }\end{array}$ \\
\hline 2. & Sensor alarm/buzzer & Untuk memberikan notifikasi bunyi \\
\hline 3. & Telemetri & $\begin{array}{l}\text { Untuk pengukuran serta pelaporan informasi } \\
\text { kepada operator }\end{array}$ \\
\hline 4. & Internal memori & Untuk menyimpan informasi yang didapat \\
\hline 5. & Sonde & Untuk menyimpan sensor-sensor \\
\hline 6. & Bluetooth & $\begin{array}{l}\text { Untuk membantu komunikasi data antara } \\
\text { sistem dan operator }\end{array}$ \\
\hline 7. & Laptop Operator & Sebagai perangkat pemantau/pengontrol \\
\hline 8. & Accu & $\begin{array}{l}\text { Untuk menyimpan energi listrik dalam bentuk energi } \\
\text { kimia }\end{array}$ \\
\hline
\end{tabular}

Perkembangan teknologi yang semakin pesat menjadikan monitoring bersifat fleksibilitas. Monitoring level sampah dapat dilakukan secara jarak jauh, sehingga operator tidak harus datang dan selalu memantau ke lokasi sungai. Monitoring ini disebut monitoring berbasis online/realtime. Skema monitoring level sampah berbasis realtime dapat dilihat pada gambar 4 di bawah ini: 


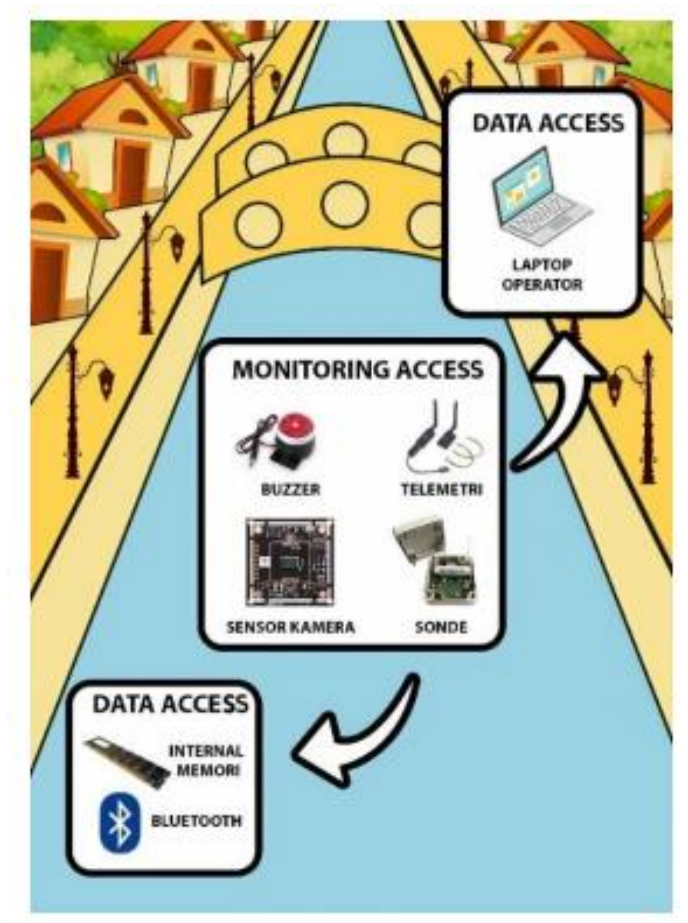

Gambar 4. Skema alat monitoring level sampah secara realtime

Parameter level sampah di sungai dapat terdeteksi melalui sensor-sensor dalam sonde. Adanya Sonde ini untuk mentransfer data ke telemetri. Selanjutnya nilai parameter akan dikirim melelui telemetri ke cloud service sehingga operator menerima notifikasi yang dapat diakses melalui PC (Personal Computer) atau laptop operator. Monitoring berbasis online/realtime menghasilkan perekaman data kondisi sungai yang dilakukan dalam jangka menit maupun jam. Sehingga level sampah di sungai dapat dipantau secara fleksibel.

Internal memori yang terdapat pada sonde dan fungsi Bluetooth melengkapi sistem monitoring online/realtime. Sehingga tak hanya data yang dapat dikirim secara online, melainkan data juga akan terekam pada internal memori atau dapat diakses melalui fungsi Bluetooth.

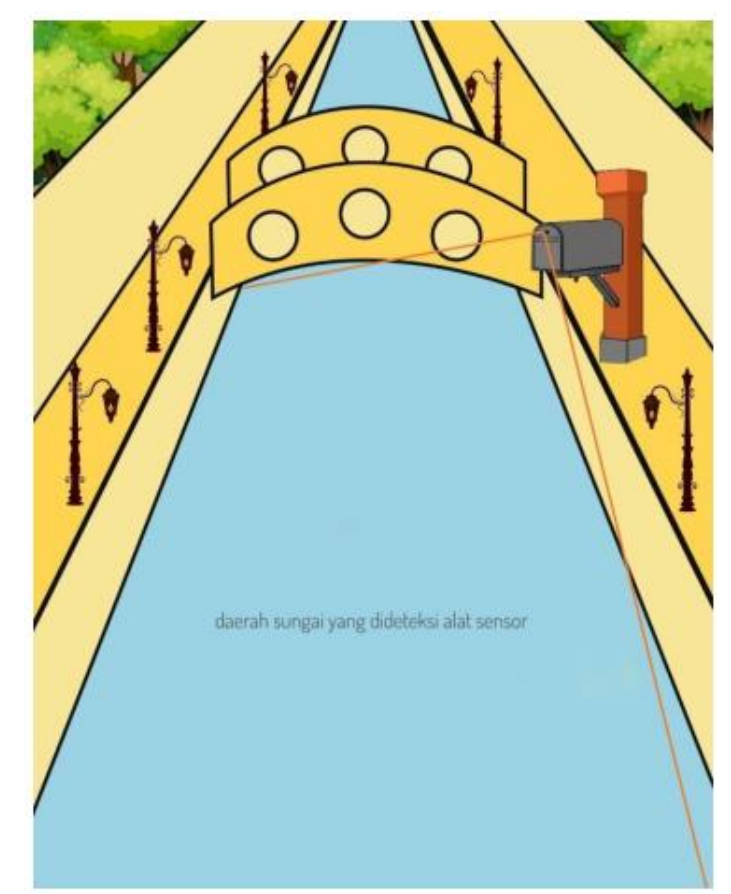

Gambar 5. Desain dan ilustrasi penempatan alat monitoring level sampah 
Alat monitoring ini diletakkan pada titik yang dapat mencakup daerah strategis dan maksimal sungai. Sensor kamera akan selalu bekerja tanpa dapat dinonaktifkan oleh masyarakat, karena hanya operator yang memegang kendali kerja alat monitoring ini. Jika suatu waktu sungai dalam kondisi kotor dan mencapai batas 50 persen dari parameter alat ini, maka arduino uno akan mengirimkan data pada sensor alarm untuk selanjutnya dilakukan proses pemilihan kondisi. Jika saja data yang diterima benar kotor adanya, maka secara otomatis buzzer akan memberikan notifikasi alarm yang dapat didengar oleh masyarakat pemukiman sekitar sungai. Buzzer akan terus berbunyi bahkan hingga menimbulkan kebisingan jika sungai tak kunjung dilakukan pembersihan atau sampai ada pengurangan indeks pencemaran sungai. Kebisingan inilah yang diharapkan dapat membuat masyarakat jera hingga tumbuh aksi peduli kebersihan lingkungan untuk saat itu dan di waktu yang akan datang.

\section{Kesimpulan}

Sensor kamera dan sensor alarm digunakan untuk monitoring level sampah pada sungai di sekitar pemukiman. Alat ini dibuat dalam bentuk prototype. Dari penelitian yang telah dilakukan maka dapat diambil kesimpulan. Sensor kamera dan sensor alarm dapat dipadukan untuk menghasilkan alat yang dapat membantu manusia, khususnya dalam mengatasi permasalahan sampah. Dengan dirancangnya alat monitoring ini diharapkan dapat menimbulkan rasa jera pada masyarakat dengan timbulnya suara bising dari sensor alarm sehingga masyarakat tergerak untuk selalu menjaga kebersihan sungai. Ke depannya, diperlukan keakuratan data lapangan terutama data lokasi pemukiman yang terdampak pencemaran sampah di sungai, sehingga bisa dilakukan penggalian data lebih lanjut agar penelitian yang dilakukan bisa lebih optimal.

\section{Daftar Pustaka}

Baqiroh, N. F. A. B. (2019). [online] https://ekonomi.bisnis.com/read/20190221/99/891611/ timbulansampah-nasionalcapai-64-juta-ton-per-tahun/ (Diakses 10 September 2020).

Firmansyah. (2015). Partisipasi Masyarakat Sekitar Sungai Kapuas dalam Menjaga Kebersihan Lingkungan di Kelurahan Ilir Kota Kecamatan Kapuas Kabupaten Sanggau. Jurnal Ilmu Sosiatri, Vol. 4, No. 2.

Hadiwiyoto, S. (1983). Penanganan dan Pemanfaatan Sampah. Yayasan Idayu.

Lestari, N. P. R., Raharjo, Y. S., dan Winardi, S. (2019). Notifikasi Kondisi Sampah Penuh Secara Realtime Melalui Smartphone. eNARODROID, 5(2), pp. 6874.

Neolaka, A. (2008). Kesadaran lingkungan. Rineka Cipta.

Notoatmojo, S. (1985). Pengantar Ilmu Perilaku. Fakultas Kesehatan Masyarakat UI, Jakarta.

Purwanto, N. (2018). Perilaku Sadar Lingkungan Pemukim Bantaran Sungai Jelai, Kabupaten Sukamara. Jurnal Pembangunan Wilayah dan Kota, Vol. 14, No. 1., pp. 41-50.

Putri, S. A. (2017). [online] http://kumpulanfeaturec 1002.blogspot.com/2017/06/bank-sampah-sungaicisadane-aksi-peduli.html (Diakses 10 September 2020).

Riswan, R., Sunoko, H. R., dan Hadiyarto, A. (2011). Pengelolaan Sampah Rumah Tangga di Kecamatan Daha Selatan. Jurnal Ilmu Lingkungan, 9(1), pp. 31-38. doi: 10.14710/ji1.9.1.31-38.

Wijaya, Y. F. dan Muchtar, H. (2019). Kesadaran Masyarakat Terhadap Kebersihan Lingkungan Sungai. Journal of Civic Education, 2(5), pp. 405-411. doi: 10.24036/jce.v2i5.297. 